\title{
ACRL Awards for 1993
}

\section{Honoring accomplishments and supporting professional development}

$\mathbf{T}$ he Association of College and Research Libraries awards program recognizes special achievements and outstanding publications and fosters professional development in academic and research librarianship. Is someone you know deserving of special recognition for their contributions to academic and research librarianship? Take a moment to nominate these outstanding individuals so they can get the recognition they deserve. Please review the requirements for each award and note those for which you or a colleague are eligible.

\section{General submission procedures}

Nominations include documentation (a letter) that indicates: 1) your name, address, and phone number, plus the name, address, and phone number of the person you are nominating; 2 ) narrative supporting the nomination (keeping in mind the award criteria); 3) a current vita.

Individuals may nominate themselves or others. Unless otherwise indicated send nominations and applications to: (Name of the Award), ACRL, 50 E. Huron St., Chicago, IL 60611.

Staff Contact: For a complete list of previous recipients or if you have questions or need help in compiling a nomination contact: Mary C. Taylor, (800) 545-2433, ext. 2515, (312) 2802515 , or U55380@uicvm.uic.edu.

\section{ACHIEVEMENT/DISTINGUISHED SERVICE}

\section{Academic or Research Librarian of the Year Award}

This award recognizes an individual member of the library profession who is making an outstanding national or international contribution to academic or research librarianship and library development.

Award: $\$ 3,000$ donated by Baker \& Taylor.

Criteria: Nominees should have demonstrated achievement in such areas as:
1. Service to the organized profession through ACRL and related organizations.

2. Significant and influential research on academic or research library service.

3. Publication of a body of scholarly and/or theoretical writing contributing to academic or research library development.

4. Planning and implementing a library program of such exemplary quality that it has served as a model for others.

Submission procedure: Send eight copies of the nominating package (see general submission procedure above).

Deadline: December 1, 1992.

Previous recipients: Carla Stoffle (1992), Richard DeGennaro (1991), Patricia Battin (1990).

\section{Miriam Dudley Bibliographic Librarian Award}

This award recognizes an individual librarian who has made an especially significant contribution to the advancement of bibliographic instruction in a college or research institution. The award honors Miriam Dudley, whose pioneering efforts in the field of bibliographic instruction led to the formation of the ACRL Bibliographic Instruction Section.

Award: \$1,000 cash donated by Mountainside Publishing Company on behalf of its publication, Research Strategies: A Journal of Library Concepts and Instruction. The award is administered by the Bibliographic Instruction Section of ACRL.

Criteria: Nominees should have achieved distinction in one or more of the following areas:

1. Planning and implementation of an academic bibliographic instruction program that has served as a model for other programs nationally or regionally.

2. Production of a body of research and publication that has a demonstrable impact on the concepts and methods of teaching and information-seeking strategies in a college or research institution.

3. Sustained participation in organizations, at the national or regional level, devoted to the promotion and enhancement of academic bibliographic instruction.

4. Promotion, development, and integration 
of education for bibliographic instruction in ALA-accredited library schools or professional continuing education programs that have served as models for other courses and programs.

Submission procedure: Send nominating package (see general submission procedure above) to: Mary Ellen Litzinger, Instructional Specialist, Pennsylvania State University, Pattee Library, University Park, PA 16802. Call Mary Ellen if you have questions or need assistance in compiling this nomination. Phone:

(814) 865-3064. Note: Nominees will be judged on an individual basis; this award cannot be given to a pair or group of persons.

Deadline: December 1, 1992.

Previous recipients: Betsy K. Baker (1992), Carla Stoffle (1991), Joan Ormondroyd (1990).

\section{Hugh C. Atkinson Memorial Award}

This award honors the life and accomplishments of Hugh C. Atkinson, one of the major innovators in modern librarianship, and recognizes outstanding achievement (including risk-taking) by academic librarians that has contributed significantly to improvements in the area of library automation, library management, and/or library development or research.

Award: $\$ 2,000$ cash and a citation. This award is funded by an endowment created by divisional, individual, and vendor contributions given in memory of Hugh C. Atkinson. Additional funds are sought to bring the endowment to at least $\$ 100,000$. Send your tax-deductible contributions to: Hugh Atkinson Memorial Award, ACRL/ALA, 50 E. Huron Street, Chicago, IL 60611. The award is jointly sponsored by the ACRL, the Association for Library Collections and Technical Services (ALCTS), the Library Administration and Management Association (LAMA), and the Library and Information Technology Association (LITA), four divisions of the American Library Association.

Eligibility: The nominee must be a librarian employed in a university, college, or community college library in the year prior to applica- tion for the award and must have a minimum of five years of professional experience in an academic library.

Criteria: Nominees must have demonstrated achievement (including risk-taking) that has contributed significantly to improvements in the area of library automation, library management, and/or library development or research.

Submission procedure: See general submission procedures above.

Deadline: December 1, 1992.

Previous recipients: Miriam Drake (1992), Donald E. Riggs (1991), Russell Shank (1990).

\section{EBSCO Community College Learning Resources/Library Achievement Awords}

These two annual awards recognize significant achievement in the areas of: 1) programs and 2) leadership.

Award: $\$ 500$ cash for each award plus citations for each award winner are donated by EBSCO Subscription Services.

Eligibility: Individuals or groups from twoyear institutions, as well as the two-year institutions themselves, are eligible to receive awards. Nominations will be kept on file for three consecutive years.

Criteria: Nominees for the program awards should demonstrate significant achievement in development of a unique and innovative learning resources/library program. Nominees for the leadership award should demonstrate significant achievement in advocacy of learning resources/library programs or services or leadership in professional organizations that are associated with the mission of community, junior, or technical colleges.

Submission procedure: Nominations should consist of the application form, a narrative letter describing achievements, and any supporting attachments. Send four copies of the nominations to: Paul E. DuMont, Director of Technical Services, Dallas County Community College District, District Service Center, 4343 N. Highway 67 , Mesquite, TX 75150-2095; (214) 324 7785. 


\section{Publications}

Now Available

From ACRL

Association Of

COLLEGE

\& RESEARCH

LIBRARIES 


\section{Management}

Recruiting the Academic Library Director: A Companion to the Search Committee Handbook

by Sharon Rogers and Ruth Person

Recruiting the Academic Library Director and the Search Committee Hardbook together offer practical advice for successfully recruiting and hiring the right director for your library. These two volumes take you through the entire recruitment process including position analysis, comprising the search committee, identifying qualifications, recruiting a good candidate pool, identifying the top candidates, interview and campus visits, and the appointment. 'The Search Committee Handbook was prepared and published by the American Association for Higher Education under the direction of an advisory committee on which Sharon Rogers served. The publications are available from ACRL only as a two volume set.

\section{\$18.65; ACRL member \$15.35 0-8389-7484-8, 1991}

Practical ideas for managing your library's programs and services are contained in ACRL's College Library Information Packets (CLIP Notes). Each CLIP Note provides data and sample documents from college and small university libraries that will assist you in establishing or refining services and operations.

\section{Audiovisual Policies in College Libraries CLIP Note \#14}

Kristine Brancolini, comp.

\$21.95; ACRL member \$18.65, 152 p. 0-8389-7495-3, 1991
Measuring Academic Library Performance: A Practical Approach

by Nancy Van House, Beth Weil, and Charles McClure

This easy-to-use set of output measures is designed to assist you in measuring the impact, efficiency, and effectiveness of academic library activities. No specialized training or knowledge of statistics is needed. The manual is also available with database software package to make data collection even easier. The software will run on any IBM-compatible microcomputer with at least $640 \mathrm{~K}$ of RAM memory and DOS 3.1 or higher.

\$32.00, 140p. 0-8389-0529-3, 1990; $\$ 75.00$ with self-running database, 0-8389-0542-0, 1991

\section{College Library Newsletters CLIP Note \#13}

Patricia Smith Butcher and Susan McCarthy Campbell, comp.

\$18.64; ACRL member \$15.35, 154p. 0-8389-7445-7, 1990

\section{Performance Appraisal in Academic Libraries CLIP Note \#12}

Barbara Williams Jenkins, comp., with the assistance of Mary L.

Smalls

\$18.64; ACRL member \$15.35, 128p. 0-8389-7444-9, 1990 
Collection Development Policies For College Libraries CLIP Note \#11

Theresa Taborsky, comp.

\$26.35; ACRL member \$21.94, 175p. 0-8389-7295-0, 1989

Annual Reports for College Libraries

CLIP Note \#10

Kenneth Oberembt, comp.

\$21.95; ACRL member \$18.75, 135p. 0-8389-7219-5, 1988

Friends of College Libraries CLIP Note \#9

Ronnelle Thompson, comp.

\$18.75; ACRL member \$15.50, 134p. 0-8389-7171-7, 1987
Periodicals in College Libraries CLIP Note \#8

Jamie Webster Hastreiter, Larry Hardesty, David Henderson, comp. \$18.75; ACRL member \$15.45, 116p. 0-8389-7143-1, 1987

Managing Student Workers in College Libraries CLIP Note \#7

Michael D. Kathman and Jane McGurn Kathman, comp.

\$18.75; ACRL member \$15.45, 182p. 0-8389-7097-4, 1986

Mission Statements for College Libraries

CLIP Note \#5

Jamie Webster Hastreiter, Larry

Hardesty, David Henderson, comp. \$21.95; ACRL member \$16.50, 107p. 0-8389-6944-5, 1985

\section{Special Collections}

This series of thesauri was developed for use in MARC field 755. Each thesaurus provides standard terms for retrieval of materials by their physical evidence of printing and publishing practices of their provenance.

Genre Terms: A Thesaurus for Use in Rare Book and Special Collections Cataloging (2nd ed.) \$21.95; ACRL member \$18.65 0-8389-7516-X, 1991

\section{Paper Terms}

\$8.95; ACRL member \$7.50, 52p. 0-8389-7427-9, 1990
Type Evidence

$\$ 8.95$; ACRL member $\$ 7.50,19 \mathrm{p}$. 0-8389-7428-7, 1990

Binding Terms \$11.50; ACRL member \$9.50, 37p. 0-8389-7210-1, 1988

Printing \& Publishing Evidence \$8.95; ACRL member \$7.50, 28p. 0-8389-7108-3, 1986

Provenance Evidence \$10.50; ACRL member \$8.50, 24p. 0-8389-7239-X, 1988 


\section{Collection Development}

\section{NEW!}

\section{Women's Studies Collection} Development Policies

WSS Collection Development and Bibliography Committee

This unique tool identifies issues and provides models of existing policies. Complete policy statements from 16 university libraries illustrate the range of issues and provide a variety of models. The RLG Conspectus; Women's Studies supplemental guideline, included as an appendix, identifies issues unique to Women's Studies and describes materials and sources.

$\$ 35.95$; ACRL member \$29.95, $122 p$. 0-8389-7596-8, 1992

\section{Books for College Libraries III}

This set covers more than 50,000 titles chosen to represent a core collection of books for four-year college and university libraries. BCL3 is also available on machinereadable tape. Contact ACRL for details.

$\$ 550.6$ v.set.

0-8389-3353-X, 1988

\section{Directory of Curriculum Materials Center, 1990}

Donald Osier, Carol Wright, Janet Lawrence, Mary Ellen Collins, Beth Anderson, comp.

This directory includes 272 institutions and covers purpose, hours, staffing, budget, service, and holdings.

\$39.54; ACRL member \$32.94, 240p. 0-8389-7439-2, 1991
Building Women's Studies Collections: A Resource Guide Joan Ariel, editor

This is no. 8 in the Bibliographical Essay Series published by Choice. Order from Choice, 100 Riverview Center, Middletown, CT 06457.

$\$ 12.00,48 p$.

0914492071, 1987

English and American Literature: Sources and Strategies for Collection Development Publications in Librarianship: No. 45

William McPheron, editor

\$32.00, 272p.

0-8389-0476-9, 1987

Richard Garnett:

The Scholar and Librarian Publications in Librarianship: No. 46

Barbara McCrimmin

$\$ 30.00,211 p$.

0-8389-0508-0, 1989

State Education Documents: A State-by-State Directory for Their Acquisition and Use

EBSS Education-Related

Government Publications Subcommittee

This directory provides the means to access the large variety of state education documents available from government agencies.

\$21.95; ACRL member \$18.65, 54p. 0-8389-7327-2, 1989 
Western European Studies:

Current Research Trends \& Library Resources

Eva Sartori, Ceres Birkhead, John Cullars, John Dillon, Thomas

Kilton, editors

Eleven research papers offer thoughtful synthesis, personal insight and information useful for anyone dealing with recent scholarship in Western European studies.

\$32.95; ACRL member \$29.65, 120p. 0-8389-7461-9, 1990
Women's Studies in Western Europe: A Resource Guide

Stephen Lehmann and Eva Sartori, editors

\$19.85; ACRL member \$16.50, 129p. 0-8389-7037-0, 1986

\section{Bibliographic Instruction}

Forthcoming

Learning to Teach: Workshops on Instruction

Practical materials to use in creating in-house staff workshops to develop or enhance teaching skills.

ISBN: 0-8389-7627-1

\section{New!}

The Evolving Educational Mission of the Library

Betsy Baker \& Mary Ellen Litzinger, editors

This book identifies strategic issues which challenge the development of instructional programs in academic libraries and suggests roles for librarians in the educational processes of their parent institutions. Academic librarians, library school educators, and higher education faculty and administrators will want this book.

\$29.95; ACRL member \$19.95, 202p. 0-8389-7584-4, 1992
Read This First: An Owner's

Guide to the New Model

Statement of Objectives for

Academic Bibliographic

Instruction

Carolyn Dusenbury, Monica

Fusich, Kathleen Kenny, and Beth

Woodard, editors

\$19.75; ACRL member \$16.45

0-8389-7548-8, 1991

Library Instruction Clearinghouses 1989: A Directory

Theresa Mensching, comp.

\$5.95; ACRL member \$4.95, 15p.

0-8389-7402-3, 1989

Back to the Books: Bibliographic Instruction and the Theory of Information Sources

Ross Atkinson, editor

\$16.50; ACRL member \$13.25, 76p. 0-8389-6587-3, 1983 


\section{Statistics $\mathcal{E}$ Research}

Forthcoming

Academic Libraries Achieving Excellence in Higher Education: Proceedings of the Sixth National Conference of the Association of College and Research Libraries ISBN: 0-8389-7622-0

\section{NEW!}

\section{ACRL University Library} Statistics, 1990-91

Library Research Center, Graduate School of Library \& Information Science, University of Illinois at Urbana-Champaign, comp.

This edition provides data on over 100 participating libraries. The categories of library data collected include: collections, personnel, expenditures, and interlibrary loan. The institutional data elements reported include degrees offered, enrollment size, and faculty size.

\$69.95; ACRL member \$39.95, 80p. 0-8389-7587-9

\section{ACRL/Historically Black} Colleges \& Universities Library Statistics, 1988-89 Robert E. Molyneux, comp.

\$35.95; ACRL member \$25.95 0-8389-7547-X, 1991

\section{ACRL University Library Statistics, 1988-89 \\ Denise Bedford, comp.}

\$49.95; ACRL member \$29.95, 79p. 0-8389-7446-5, 1990

\author{
ACRL University Library \\ Statistics, 1987-88 \\ Robert E. Molyneux, comp.
}

\$49.95; ACRL member \$29.95, 79p. 0-8389-7288-8, 1989

\author{
ACRL Academic Library \\ Statistics, 1978/79-1987/88 \\ (Diskettes)
}

\$65.95; ACRL member $\$ 53.95$ 0-8389-7311-C, 1989

Library Statistics of Colleges \& Universities, 1985; National Summaries, State Summaries, Institutional Tables

Data on 3,000 academic libraries from the 1985 HEGIS study conducted by the Center for Education Statistics

\$33.50; ACRL member \$26.45, 140p. 0-8389-7147-4, 1987

Academic Libraries: Research Perspectives

Publications in Librarianship:

No. 47

Mary Jo Lynch and Arthur P.

Young, editors

\$27.50; 256p.

0-8389-0532-3, 1990 
Building on the First Century:

Proceedings of the Fifth

National Conference of the

Association of College and

Research Libraries

Jan Fennell, editor

\$32.85; ACRL member \$24.25, 320p.

0-8389-7289-6, 1989
Energies for Transition:

Proceedings of the Fourth

National Conference of the

Association of College and

Research Libraries

Danuta A. Nitecki, editor

\$32.85; ACRL member \$24.25, 248p. 0-8389-6976-3, 1986

\section{News $\mathcal{E}$ Reviews}

\section{Choice}

Book review journal of the Association of College and Research Libraries (ACRL). Eleven issues per year (July / August combined).

ISSN: 0009-4978. Available by subscription only, $\$ 148 /$ year domestic rate; $\$ 165 /$ year foreign rate; single issues $\$ 15.00$. Also available as:

\section{Choice-Reviews-on-Cards}

Reviews from each monthly issue of Choice printed on $3 \times 5$ cards. Available to Choice subscribers only for $\$ 225 /$ year domestic rate; $\$ 245$ /year foreign rate, sample box $\$ 25.00$. Order either Choice product from: Circulation Department, Choice, 100 Riverview Center, Middletown, CT 06457, (203) 347-6933.

\section{Rare Books and Manuscripts Librarianship}

A journal of theory and practice covering all aspects of special collections librarianship. Two issues/ year. ISSN: 0884-450X. \$25.00 U.S.; $\$ 30.00$ for institutions in the U.S.; $\$ 35.00$ for Canada and Mexico; $\$ 45.00$ overseas; single issues $\$ 15.00$.

\section{College and Research Libraries}

Official journal of the Association of College and Research Libraries. Six bimonthly issues per year. Sent to ACRL members as a perquisite of membership. Also available on subscription, \$45/year; single issues $\$ 8.50$. ISSN: 0010-0870.

\section{College and Research Libraries News}

Official news magazine of the Association of College and Research Libraries. Eleven issues per year (July/August combined). Sent to ACRL members as perquisite of membership. Also available on subscription, $\$ 20$ / year; single issues $\$ 4.50$. ISSN: 0099-0086.

\section{College \& Research Libraries} and College \& Research Libraries News, Index for Volumes 41-50 (1980-89)

\$29.95; ACRL member \$25.95 0-8389-7487-2, 1991 


\section{Ordering Information}

1. Fill in your shipping and billing addresses.

2. Check the items you wish to order. Indicate a quantity and sub-total. Add appropriate handling charges.

3. Select a method of payment. ACRL pays postage and handling charges for prepaid orders (check, money order, credit card).

4. Mail the order form to:

American Library Association

Order Department

50 East Huron Street

Chicago, IL 60611

For faster, more personal service, call toll-free 1-800-545-2433, Press 7.

Terms of Business. Institutions and individuals may order on account, plus postage and handling. Prepayment should accompany individuals' orders of $\$ 30$ or less. Shipping and handling charges will be added to all orders. All prices are payable in U.S. funds, net 30 days. First price is list price.

Discounts. ALA personal and organizational members are eligible to receive a ten percent (10\%) discount on ACRL materials (except subscription items). To receive the discount, give your membership number, and deduct the discount when preparing your orders. ACRL personal and organizational members receive 10$30 \%$ discount on non-subscription ACRL materials. Look for the ACRL member price in this booklet. 


\section{Price}

$\$ 27.50$

$\$ 69.95 / 39.95$

$\$ 49.95 / 29.95$

$\$ 49.95 / 29.95$

$\$ 65.95 / 53.95$

$\$ 21.95 / 18.75$

$\$ 21.95 / 18.65$

$\$ 16.50 / 13.25$

$\$ 11.50 / 9.50$

$\$ 550$

$\$ 32.85 / 24.25$

$\$ 26.35 / 21.94$

$\$ 18.64 / 15.35$

$\$ 29.95 / 25.95$

$\$ 39.54 / 32.94$

$\$ 32.85 / 24.25$

$\$ 32.00$

$\$ 29.95 / 19.95$

$\square \$ 18.75 / 15.50$

$\square \$ 21.95 / 18.65$

$\square \$ 35.95 / 25.95$

$\square 5.95 / 4.95$

$\square \$ 33.50 / 26.45$

$\square \$ 18.75 / 15.45$

$\square \$ 32.00$

$\square \$ 75.00$

$\square \$ 21.95 / 16.50$

$\square \$ 8.95 / 7.50$

$\square \quad \$ 18.64 / 15.35$

$\square \$ 18.75 / 15.45$

$\square \$ 8.95 / 7.50$

$\square \$ 10.50 / 8.50$
0-8389-

0532-3-992A

7587-9-992A

7446-5-992A

7288-8-992A

7311-C-992A

7219-5-992A

7495-3-992A

6587-3-992A

7210-1-992A

3353-X-992A

7289-6-992A

7295-0-992A

7445-7-992A

7487-2-992A

7439-2-992A

6976-3-992A

0476-9-992A

7584-4-992A

7171-7-992A

7516-X-992A

7547-X-992A

7402-3-992A

7147-4-992A

7097-4-992A

0529-3-992A

0542-0-992A

6944-5-992A

7427-9-992A

7444-9-992A

7143-1-992A

7108-3-992A

7239-X-992A

\section{Title}

Academic Lib. Research

ACRL Stats 90/91

ACRL Stats 1988/89

ACRL Stats 1987/88

ACRL Stats 78/79-87/88 (Diskettes)

Annual Reports

A-V Policies

Back to the Books

Binding Terms

Books for College Lib.

Building on 1st Century

Collection Dev. Policies

College Lib. Newsletters

C\&RL and C\&RL News Index v. 41-50

Dir. of Curriculum Centers

Energies for Transition

English \& American Lit.

Evolving Educational Mission

Friends of College Lib.

Genre Terms

HBCU Stats $88 / 89$

Lib. Instruc. Clear. 1989

Library Statistics 1985

Managing Student Work.

Measuring Acad. Lib. Perf.

Measuring.. (disk \& book)

Mission Statements

Paper Terms

Performance Appraisal

Periodicals in College Lib.

Printing \& Pub. Evidence

Provenance Evidence 


\begin{tabular}{|c|c|c|c|}
\hline$\square$ & $\$ 19.75 / 16.45$ & $7548-8-992 A$ & Read This First \\
\hline$\square$ & $\$ 18.65 / 15.35$ & 7484-8-992A & Recruiting Acad. Lib. Dir. \\
\hline$\neg$ & $\$ 30.00$ & $0508-0-992 \mathrm{~A}$ & Richard Garnett \\
\hline$\square$ & $\$ 21.95 / 18.65$ & $7327-2-992 A$ & State Education Doc. \\
\hline 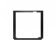 & $\$ 8.95 / 7.50$ & $7428-7-992 \mathrm{~A}$ & Type Evidence \\
\hline$\square$ & $\$ 32.95 / 29.65$ & $7461-9-992 A$ & Western European Studies \\
\hline$\square$ & $\$ 19.85 / 16.50$ & $7037-0-992 \mathrm{~A}$ & $\begin{array}{l}\text { Women's Studies in West. } \\
\text { Europe }\end{array}$ \\
\hline$\square$ & $\$ 35.95 / 29.95$ & $7596-8-992 A$ & $\begin{array}{l}\text { Women's Studies Collection } \\
\text { Dev. Policies }\end{array}$ \\
\hline$\$$ & \multicolumn{3}{|l|}{ Subtotal } \\
\hline & \multirow{2}{*}{\multicolumn{3}{|c|}{$\begin{array}{l}\text { Handling charges............. Handling charges } \$ 3.75 \text { up to } \$ 19.99 ; \\
\begin{array}{l}\$ 4.75 \text { for } \$ 20 \text { to } \$ 49.99 ; \$ 6.50 \text { for } \$ 50 \\
\text { to } \$ 74.99 ; \$ 7.50 \text { for } \$ 75 \text { to } \$ 149.99 ; \\
5 \% \text { of total order for } \$ 150+.\end{array}\end{array}$}} \\
\hline$\$$ & & & \\
\hline
\end{tabular}

Ship to:

Bill to:

Check/money order enclosed

Charge my credit card:

MasterCard

VISA

American Express

Card Number:

Expires:

Signature:

Send Invoice (term 30 days)

Signature: 


\section{ACRL Approval Plans}

ACRL publications provide practical ideas, tools and methods for: management, bibliographic instruction, special collections, collection development, statistics \& research.

The convenient and cost-cutting ACRL approval order plan provides automatic priority shipping of ACRL's new books at a $20 \%$ discount to ACRL members ( $10 \%$ to non-members).

There are two approval plan categories from which to choose:

Plan $P$ guarantees that you will automatically be sent all new ACRL publications including CLIP Notes. ACRL publishes approximately 5 to 6 new titles each year.

Plan PC is exclusively for titles in the CLIP Notes (College Library Information Packets) series. CLIP Notes collect data and sample documents from academic libraries to assist librarians in establishing or refining services and operations.

Easy to enroll. Call or write Mary C. Taylor, ACRL program officer, indicating the category you have chosen. (ACRL/ALA, Approval Plan, 50 East Huron Street, Chicago, IL 60611; 1-800-545-2433 ext. 2515). 
$\frac{\frac{\text { Association Of }}{\text { COLLEGE }}}{\frac{\text { \& RESEARCH }}{\text { LIBRARIES }}}$ 
Deadline: December 1, 1992.

Previous recipients: Leadership or Community Service: Paul E. DuMont (1992); James O. Wallace (1991); Charles R. Peguese (1990). Program Development: The Library Collection Development Committee at St. Petersburg (FL) Junior College (1992); Jimmie Anne Nourse and Rudy Widman (1991); The Cooperative Collection Development Committee of the Chemeketa Cooperative Regional Library Services (1990)

\section{PROFESSIONAL DEVELOPMENT AND RESEARCH}

\section{Doctoral Dissertation Fellowship}

This award fosters research in academic librarianship by encouraging and assisting doctoral students in the field with their dissertation research.

Award: $\$ 1,000$ cash and citation donated by the Institute for Scientific Information.

Eligibility: The recipient of the fellowship must meet the following qualifications:

1. Be an active doctoral student in the academic librarianship area in a degree-granting institution.

2. Have completed all coursework.

3. Have had a dissertation proposal accepted by the institution.

4. A recipient of the fellowship may not receive it a second time.

5. Applicant need not be an ACRL member.

Criteria: The proposal will be judged primarily on merit with emphasis on the following:

1. Potential significance of the research to the field of academic librarianship. (No attempt will be made to define academic librarianship but the subject should be consistent with topics usually published in College \& Research $\mathrm{Li}$ braries or presented at ACRL meetings.)

2 . Validity of the methodology and proposed methods of analysis.

3. Originality and creativity.

4. Clarity and completeness of the proposal.

5. Presentation of a convincing plan for completion in a reasonable amount of time.

6 . Evidence of a continuing interest in scholarship such as a previous publication record.

Submission procedure: Qualified students who wish to be considered for the fellowship may apply by submitting a brief (ten pages or less double-spaced) proposal that includes:

1. Description of the research, including significance and methodology.

2. Schedule for completion.
3. Budget and budget justification for items for which support is sought. (Must be items for which no other support is available.)

Examples of acceptable budget items are printing, computer time, fees to subjects, statistical consulting, photography, art work, typing, and professional travel.

4. Name of dissertation advisor and committee members.

5. Cover letter from dissertation advisor endorsing the proposal.

An up-to-date curriculum vitae should accompany the proposal. Because of limits imposed by timing considerations, applications may be made for research under way; e.g., a student who begins research in the fall may apply for support for expenses incurred from the fall until the time the award is made.

Deadline: December 1, 1992.

\section{Martinus Nijhoff International West European Specialist Study Grant}

This grant supports research on Western European studies, librarianship, or the book trade.

Award: A maximum of 10,000 Dutch guilders (or U.S. dollar equivalent) donated by Martinus Nijhoff International, a subscription agent and book dealer with headquarters in The Netherlands. This study grant covers air travel to and from Europe, transportation in Europe, and lodging and board for no more than 14 consecutive days. Funds may not be used for salaries, research-related supplies, publication costs, conference fees, or equipment purchases.

Criteria: The primary criterion for awarding the grant is the significance and urility of the proposed project as a contribution to the study of the acquisition, organization, or use of library materials from or relating to Western Europe. Current or historical subjects may be treated. The award jury will review proposals with the following in mind:

1. What is the work to be accomplished? The proposal should be as explicit as possible about the current state of knowledge in the area and what will be achieved by the successful completion of the study.

2. What is the need for and value of the proposed research? The proposal should provide persuasive evidence that the study is of practical use or scholarly value to the wider community served by the grant.

3. What is the methodology for carrying out the proposed work? The research design should 


\section{Tops among ARL librarians!}

\section{Social SciSearch with Abstracts.}

It's no wonder that the librarians from the Association for Research

Libraries rank Social SciSearch with Abstracts as the top multidisciplinary social sciences online database.*

Not only does it feature fully searchable author abstracts, it provides the most current bibliographic data available.. from three months to a year sooner than any other database! It's multidisciplinary too, so you'll retrieve complete information on every item related to your search...no matter where in the journal literature it was published.

And because only ISI's online files offer cited reference searching, you'll uncover important information that you simply would not find using any other online source.

Social SciSearch with Abstracts...The First Choice for online information. Available on BRS, DATA-STAR, DIALOG and DIMDI.

- (ONLNE, March 1992, p. 26) 
be as specific as possible and demonstrate why the European component is essential.

4. Is the work accomplishable within the time frame proposed? If the study extends beyond the 14-day limit of the grant, the proposal should specify how the additional work will be completed and funded.

5. Are the applicant's qualifications sufficient to carry out the study?

Submission procedure: Send six (6) copies of the application, which includes:

1. A proposal, five (5) pages or less, typed double-spaced.

2. A tentative travel itinerary not to exceed 14 days, including the proposed countries and institutions to be visited and the preferred period of study/travel.

3. A travel budget, including estimated round-trip coach airfare, transportation in Europe, lodging expenses, and meal costs.

4. A current curriculum vitae.

Obligations of the Grantee: The recipient's detailed expense statement, with original receipts, is due to ACRL within two months of the trip's termination. The grantee is required to submit a report to ACRL within six months of no less that 4,000 words on the research resulting from the study trip. It is assumed that in most cases this report will be suitable for publication; if so, ACRL is given the first right of refusal. The grantee should submit an abstract of the report for publication in the WESS Newsletter. In addition, the grantee may be asked to participate in a WESS general discussion group, advise the award jury, or counsel new grantees. Recipients are encouraged, but not required, to join WESS and become involved in its activities.

Deadline: December 1, 1992.

\section{Samuel Lazerow Fellowship for Research in Acquisitions or Technical Services in an Academic or Research Librory}

This award fosters advances in acquisitions or technical services by providing librarians a fellowship for travel or writing in those fields. Research projects in collection development or the compilation of bibliographies will not be supported by this fellowship.

Award: $\$ 1,000$ cash and a citation donated by the Institute for Scientific Information.

Criteria: The proposals will be judged with an emphasis on the following:

1. Potential significance of the project to acquisitions or technical services work.

2. Originality and creativity.

3. Clarity and completeness of the proposal.

4. Evidence of an interest in scholarship, such as a previous publication record.

Submission procedure. Brief proposals (five pages or less, double-spaced) should include the following:

1. Description of research, travel, or writing project.

2. Schedule for project.

3. Estimate of expenses (e.g., professional travel, computer time, photocopying, typing.)

4. Recipients of the fellowship will be asked to submit a brief report of the results of their research.

5. An up-to-date curriculum vitae should accompany proposal.

Deadline: December 1, 1992.

\section{PUBLICATIONS OR ARTICLES}

\section{Katharine Kyes Leab and Daniel J. Leab, American Book Prices Current, Exhibition Catalogue Awards}

These awards recognize outstanding catalogs published by American or Canadian institutions in conjunction with exhibitions of books and/ or manuscripts.

Award: A printed citation to the winning institutions organizing the exhibitions. Katherine Kyes Leab and Daniel J. Leab, American Book Prices Current, established an endowment to fund the awards.

Eligibility: Catalogs published by American or Canadian institutions in conjunction with an exhibition of books and/or manuscripts which has taken place or which is in progress before August 31, 1992, are eligible. Catalogs must be published between September 1, 1991, and August 31, 1992. The entries will be divided into three budget categories - expensive, moderately expensive, and inexpensive-based upon the production costs as outlined in the entry form. Catalogs may be of varying formats, styles, and scope, but each must represent an exhibition which has taken place. Catalogs may be intended for various types of audiences: e.g., scholars, students, general public. Catalogs may have various purposes: e.g., publicity, dissemination of information about a collection, attraction of donations, commemoration of a special occasion, etc.

Criteria: Catalogs will be judged on the level of accuracy and consistency of presentation, 
their clarity, quality of design, and usefulness to the intended audience.

Submission procedure. Four (4) copies of the catalog must be submitted with an entry form (available from the chair of the committee) to the chair: Marvin J. Taylor, Special Collections, Columbia University, Health Sciences Library, 701 W. 168th Street, New York, NY 10032. All catalog submissions will become the property of RBMS. If you have any questions, call Marvin Taylor at (212) 305-7931.

Deadline: September 30, 1992.

\section{K.G. Saur Award for Best Article in College \& Research Libraries}

This recognizes the most outstanding article published in College $\&$ Researcb Libraries ( $C G R L)$ during the preceding volume year.

Award: A citation and $\$ 500$ cash to each author donated by K.G. Saur.

Eligibility: Articles published in CERL during the preceding volume year.

Criteria: The winning article will be selected on the basis of originality, timeliness, relevance to ACRL areas of interest and concern, and quality of writing.

Submission procedure. Articles for CERL may be submitted to: Gloriana St. Clair, Assistant Dean for Access Services, E506 Pattee Library, Pennsylvania State University, University Park, PA 16802.

\section{Rare Books \& Manuscripts Librarianship Award}

This award stimulates the contribution of articles of superior quality to the ACRL joumal Rare Books and Manuscripts Librarianship (RBML).

Award: $\$ 1,000$ cash to each author and a citation donated by Christie, Manson \& Woods.

Eligibility: Article published in RBML during the two preceding volume years.

Criteria: The winning article will be selected on the basis of significance, originality, timeliness, thoroughness, and pertinence to issues relating to the. theory and practice of special collections librarianship. Other criteria will include clarity of thought and expression.

Submission procedure: Articles for RBML may be submitted to: Alice D. Schreyer, University of Chicago Library, Chicago, IL 60637.

\section{BIS Bibliographic Instruction Publication of the Year Award}

This award recognizes an outstanding publication related to bibliographic instruction published in a given year.
Award: A citation presented by the BIS Awards Committee.

Criteria: Publications are judged on the basis of relevance to the field of bibliographic instruction in academic or research libraries, originality, timeliness, and quality of writing.

Eligibility: Publications include journal articles, books, and book chapters. Submitted publications may be authored by one or more individuals, a group, organization, or committee. BIS publications are not eligible for consideration for the award. Publication year is defined as September through August of the year preceding the year the award is given.

Submission procedure: Submit a two-page summary, a copy of the publication, and nomination form (available from the committee chair) to: Karen William, Committee Chair, Central Reference Library, University of Arizona, Tucson, AZ 85719; (602) 621-4865.

Deadline. December 1, 1992.

\section{Oberly Award for Bibliography in Agricultural Sciences}

The Oberly Award was established in 1923 in memory of Eunice Rockwood Oberly. This biennial award is given in odd-numbered years for the best English-language bibliography in the field of agriculture or related science.

Award: A cash award and citation currently funded by the U.S. Agricultural Information Network, the Agway Foundation, Associates of the National Agricultural Library, the Council on Botanical and Horticultural Libraries, and the Cargill Information Center.

Eligibility: English-language bibliographies in the field of agriculture or a related science compiled during the two-year period preceding the year in which the award is made.

Criteria: Bibliographies submitted for award consideration are judged on accuracy, scope, usefulness, format, and special features: explanatory introductions, annotations, and indexes.

Submission procedure: Nominations may be made in the form of a letter and should point out the reasons the bibliography should be considered for the award. A copy of the bibliography should accompany the nomination. Send nominations to: Oberly Jury Chair, Amy L. Paster, Pennsylvania State University, E205 Pattee Library, University Park, PA 16802 .

Deadline: December 1, 1992. 


\section{DefinItIVE Resources inflimfromK.G.Sour...}

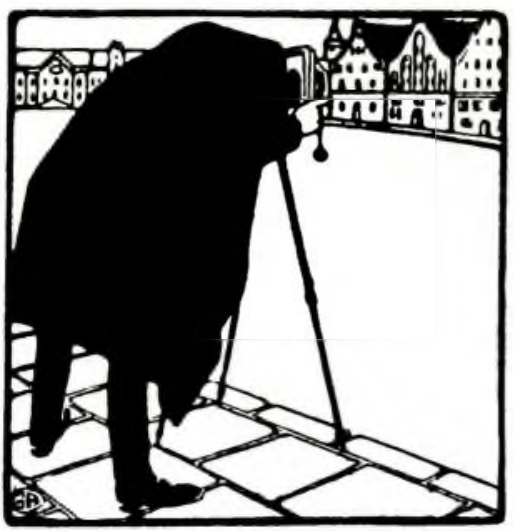

\section{International Film Index}

Edited by Alan Goble

This is the most exhaustive film directory and director's filmography ever compiled. It lists $90 \%$ of all American, European, and Australasian feature films ever made more than 232,000 film titles, and includes shorts, animated features, documentaries, serials and even TV films, spanning the entire era of moving pictures.

Arranged alphabetically, the Director's entries list dates of birth and death; country of birth and filmmaking; and a complete chronology of films with dates and alternative titles. Title entries contain year of release, director, country of film finance, type of film and alternative title. Supplementary indexes of directors by country, and a massive bibliography further augment the value of this work.

$1991 / 0-86291-632-2 / 1,600$ pages $/ \$ 335$

\section{Pre-Cinema History}

An Annotated Bibliography

Dr. Hermann Hecht and Anne Hecht

The Camera Obscura outlined by Da Vinci, the Magick Lantern devised in the 17th century, the Thaumatrope and the Phénakistoscope-these are some of the optical inventions which led to the emergence of film. They represent a fraction of the 4,500 entries contained in PRE-CINEMA HISTORY, a worldwide bibliography of moving picture representations spanning six centuries.

Arranged in chronological order, each notable object or occasion is described and set in its historical context. Full bibliographic references with contents summaries and quotations from the original article and contemporary press clippings are also provided.

1992/C. 800 pages/\$180 T.

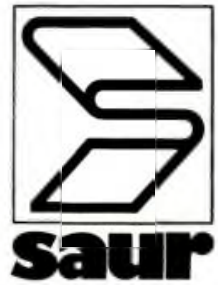

For Fastest Service Call Toll-Free $1-800-521-8110$ 